\title{
SYSTEMATIC LITERATURE REVIEW: KUALITAS LAPORAN KEUANGAN PADA KOPERASI
}

\author{
Riska Dyah Ayu Utami ${ }^{1}$, Dwi Cahyono ${ }^{2}$, Rendy Mirwan Aspiradi ${ }^{3}$ \\ 1,2,3Universitas Muhammadiyah Jember, riskadyah62@gmail.com; \\ dwicahyono@unmuhjember.ac.id; rendymirwanaspirandi@unmuhjember.ac.id
}

\begin{abstract}
ABSTRAK
Penelitian ini bertujuan untuk mengisi kesenjangan penelitian dengan memberikan tinjauan pustaka sistematis untuk mengetahui dan menganalisis mengenai faktor-faktor yang mempengaruhi kualitas laporan keuangan pada koperasi. Pada metode penelitian ini mengukuti proses tinjauan pustaka sistematis yang terdiri dari tahap utama: perencanaan tinjauan, pelaksanaan tinjauan, dan pelaporan tinjauan. Studi awal yang telah ditemukan 561 artikel penelitian dan total studi yang digunakan 10 untuk tinjauan pustaka sistematis ini berdasarkan kriteria inklusi dan eksklusi. Data kuantitatif yang diektraksi dari literatur yang dipilih mengikuti strategi ekstraksi data dalam empat ekstraksi data. Data yang telah diestraksi disintesiskan untuk merumuskan pertanyaan penelitian yang telah dikemukakan untuk mendapatkan tujuan review. Hasil tinjauan Systematic Literature Review dari semua penelitian yang terdapat pada jurnal yang dipublikasikan dari tahun 2015-2020 menyatakan bahwa faktor yang mempengaruhi kualitas laporan keuangan koperasi sangatlah beragam yaitu sumber daya manusia, pengendalian internal akuntansi, pemanfaatan teknologi informasi, pengalaman kerja, pemahaman akuntansi, pengaruh stres kerja, tingkat pendidikan, budaya etis organisasi. Faktor utama yang mempengaruhi adalah pengendalian internal akuntansi dimana koperasi sebaiknya memberikan pemahaman akuntansi dan meningkatkan pengendalian internal agar kualitas laporan keuangan tidak akan terjadi kecurangan pada koperasi.
\end{abstract}

Kata kunci: Tinjauan Pustaka Sistematis, Kualitas Laporan Keuangan, Koperasi

\begin{abstract}
This study aims to fill the research gap by providing a systematic literature review to identify and analyze the factors that affect the quality of financial reports in cooperatives. This research method follows a systematic literature review process which consists of the main stages: planning the review, implementing the review, and reporting the review. The initial study found 561 research articles and a total of 10 studies used for this systematic literature review based on inclusion and exclusion criteria. The quantitative data extracted from the selected literature followed the data extraction strategy in four data extractions. Extracted data is synthesized to formulate research questions that have been raised for review purposes. The results of the Systematic Literature Review of all research contained in journals published from 2015-2020 state that the factors that affect the quality of cooperative financial reports are very diverse, namely human resources, internal accounting controls, use of information technology, work experience, understanding of accounting, influence job stress, level of education, ethical culture of the organization. The main factor influencing is internal accounting control where cooperatives should provide accounting understanding and improve internal control so that the quality of financial reports will not occur cheating on cooperatives.
\end{abstract}

Keywords: Systematic Literature Review, Quality of Financial Statements, Cooperatives

Naskah diterima : 13-04-2021, Naskah dipublikasikan : 30-04-2021 


\section{PENDAHULUAN}

Perkembangan perekonomian yang sekarang di hadapi oleh dunia usaha termasuk koperasi bisa dikatakan kedalam kategori perkembangan yang cepat dan dinamis, dimulai dari usaha kecil, menengah maupun keatas baik dalam bidang industri dagang, jasa maupun manufaktur dan juga dalam bidang lembaga jasa keuangan seperti koperasi. Koperasi sendiri sebagai organisasi yang bergerak dalam bidang perekonomian dan sosial dapat dikatakan sebagai salah satu organisasi yang rawan akan tingkat risiko kerugian yang dapat menjadi penyebab koperasi tersebut menjadi non aktif. Tingkat rawan risiko dari koperasi sering di akibatkan dari berbagai faktor internal ataupun eksternal koperasi, mulai dari kecurangan yang ditimbulkan oleh perseorangan anggota atau pengurus koperasi yang mengutamakan kepentingan pribadinya sehingga memanfaatkan kesempatan dari kelemahan koperasi itu sendiri Sapitri et al. (2016).

Menurut Roviyantie (2011) Laporan keuangan adalah bidang atau disiplin ilmu akuntansi yang dapat menghasilkan suatu produk. Oleh karena itu untuk mengahasilkan kualitas laporan keuangan yang berkualitas. Sama halnya dengan koperasi, untuk mencapai laporan keuangan yang berkualitas dan bermutu sangatlah penting untuk memperhatikan sumber daya manusia yang berkompeten dalam akuntansi laporan keuangan. Untuk mencapai dan meningkatkan kualitas laporan keuangan membutuhkan dukungan pegawai untuk dilibatkan dalam proses penyusunan laporan keuangan yang harus dipahami agar mengerti bagaiamana cara dan proses dalam menjalankan akuntansi yang sesuai dengan pedoman dan ketentuan yang berlaku pada koperasi itu sendiri.

Banyaknya koperasi yang tidak aktif di Indonesia menyebabkan kualitas laporan keuangan pada koperasi ini menyebabkan kecurangan, laporan keuangan yang melemah dan banyaknya faktor yang mempengaruhi bahwa kualitas laporan keuangan tidak stabil Sapitri et al. (2016). Objek dari penelitian ini adalah koperasi yang bergerak dalam bidang jasa. Berdasarkan hasil observasi bahwa kualitas laporan keuangan adalah hal paling penting bagi koperasi untuk mendapatkan kualitas laporan keuangan pada koperasi itu sendiri dibandingkan dengan para pesaingan lainnya. Sehingga kualitas laporan keuangan ini juga dapat mempengaruhi sumber daya manusia dan pengendalian pada koperasi itu sendiri, karena adanya faktor persaingan yang banyak antar koperasi yang ada.

Riyadi (2020) dimana pemanfaatan sistem informasi berpengaruh positif dan signifikan dalam kualitas laporan keuangan yaitu dimana laporan keuangan yang berkualitas dibutuhkan orang-orang yang dapat menyusun laporan keuangan dan menjadi perhatian utama, oleh karena itu anggota atau karyawan yang terlibat dalam aktivitas mampu memahami proses dan pelaksanaan dengan ketentuan yang berlaku. Maka banyaknya penelitian yang membahas tentang faktor-faktor tentang kualitas laporan keuangan juga banyak ditemukan ketidak konsistenan dari hasil penelitian. Selain itu juga review dalam membahas tentang kualitas laporan keuangan pada koperasi masih sangat minim dan masih banyaknya kecurangan-kecurangan yang terjadi pada koperasi. Sampai sejauh ini, belum ada systematic literature review yang membahas mengenai kualitas laporan keuangan pada koperasi.

Riset mengenai kualitas laporan keuangan sudah banyak penelitian yang membahas tentang faktor-faktor tentang kualitas laporan keuangan juga banyak ditemukan ketidak konsistenan dari hasil penelitian. Selain itu juga review dalam membahas tentang kualitas laporan keuangan pada koperasi masih sangat minim dan masih banyaknya kecurangan-kecurangan yang terjadi pada koperasi. Maka dari itu, riset ini dibuat menggunakan metode studi kepustakaan serta memberikan informasi dengan mengkaji terhadap penelitian sebelumnya, yang bertujuan untuk mengisi dan menganalisis kesenjangan penelitian dengan memberikan analisis kualitas laporan keuangan pada koperasi secara luas. 


\section{KAJIAN LITERATUR \\ Systematic Literature Review}

Suryani (2014) menyatakan bahwa Systematic Literature Review atua sering disebut sebagai tinjauan pustaka sistematis adalah istilah yang sering digunakan dalam menunjukan sebuah rujukan pada metodelogi penelitian atau riset tertentu dalam pengembangan yang bertujuan untuk mengumpulkan dan mengavaluasi penelitian yang berkaitan dengan fokus topik tertentu. Metode pada tinjauan pustaka sistematis ini dapat dilakukan dengan sistematis tetapi tetap mengikuti protokol yang telah ada yang bersofat subyektif dari suatu penelitian.

\section{Kualitas Laporan Keuangan}

Baridwan (2004) menyatakan bahwa setiap laporan keuangan adalah sebuah catatan atau sebagai kegiatan transaksi dalam suatu kegiatan organisasi atau perusahaan yang dimana catatan tersebut diringkas dalam satu tahun. Laporan keuangan ini dapat dibuat juga oleh manajemen sebagai pertanggung jawaban tugas-tugas yang dibebankan untuk memenuhi tujuan lain seperti lapatau pihakpihak di luar suatu peusahaan.

Sedangkan Munawir ( 2000) mengemukakan bahwa laporan keuangan adalah sebagai alat yang dapat digunakan untuk mendapatkan sebuah informasi tentang posisi laporan keuangan dan sebagai hasil sejauh mana pencapaian koperasi perusahaan dalam satu tahun. Dari pendapat Munawir bisa ditarik kesimpulan bahwa laporan keuangan adalah sebuah catatan atau kegiatan dalam perusahaan yang berupa angka-angka yang didalamnya memuat sebuah informasi penting dan kondisi dimana kinerja perusahaan dalam berjalan baik dalam satu tahun

\section{Koperasi}

Menurut ojk.go.id (1992) menyatakan bahawa pengertian koperasi memiliki 2 pengertian, yaitu pengertian secara umum dan menurut koperasi itu sendiri. Untuk pengertian umum koperasi merupakan sebuah perkumpulan yang memiliki beberapa anggota atau badan hukum koperasi itu sendiri, dimana dapat memberikan keluar masuk sebagai anggota, dengan syarat mamapu bekerjasama secara kekeluargaan.

Hendrojogi (1997) mengemukakan bahwa koperasi merupakan suatu kelompok dalam bentuk badan usaha yang memiliki atau badan hukum yang kegiatannya didasarkan pada prinsip koperasi dan sebagai gerakan ekonomi rakyat yang berlandaskan kekeluargan. Maka dapat diartikan sebagaimana mestinya pengertian koperasi dapat diatur dalam Undang-Undang Perkonomian Indonesia yang menjelaskan pengertian koperasi.

Peraturan BPK (1967) berpendapat bahwa koperasi juga dapat didefinisikan sebagai perkumpulan orang-orang yang tidak memandang agama dan politik, oleh sebab itu koperasi dapat dimasuki dan bergabung secara suka rela atau hanya sekedar untuk memenuhi kebutuhan bersama yang bersifat kebendaan atas tanggungan bersama. Tujuannya untuk mensejahterahkan anggota dan masyarakat luas yang pada hakikatnya mengandung unsur demokrasi, sosial, dimana tujuan koperasi ini tidak hanya mencari keuntungan semata-mata.

\section{METODE PENELITIAN Rancangan Penelitian}

Metode yang digunakan pada penelitian ini adalah metode Systematic Literature Review atau SLR. Menurut (Kitchenham dan Charters, 2007) menyatakan bahwa yang telah diuraian latar belakang dan rumusan masalah sebelumnya yang dijelaskan oleh peneliti. Pada metode Systematic Literature Review atau biasa disebut dengan metode penelitian tinjauan pustaka sistematis adalah salah satu metode dalam penelitian yang mengidentifikasi, menilai, dan menginterpretasi terhadap masalahmasalah yang ada pada suatu topik permasalahan, serta guna menjawab pertanyaan penelitian yang telah dijelaskan. Metode SLR ini memiliki beberapa tahapan, yaitu: 


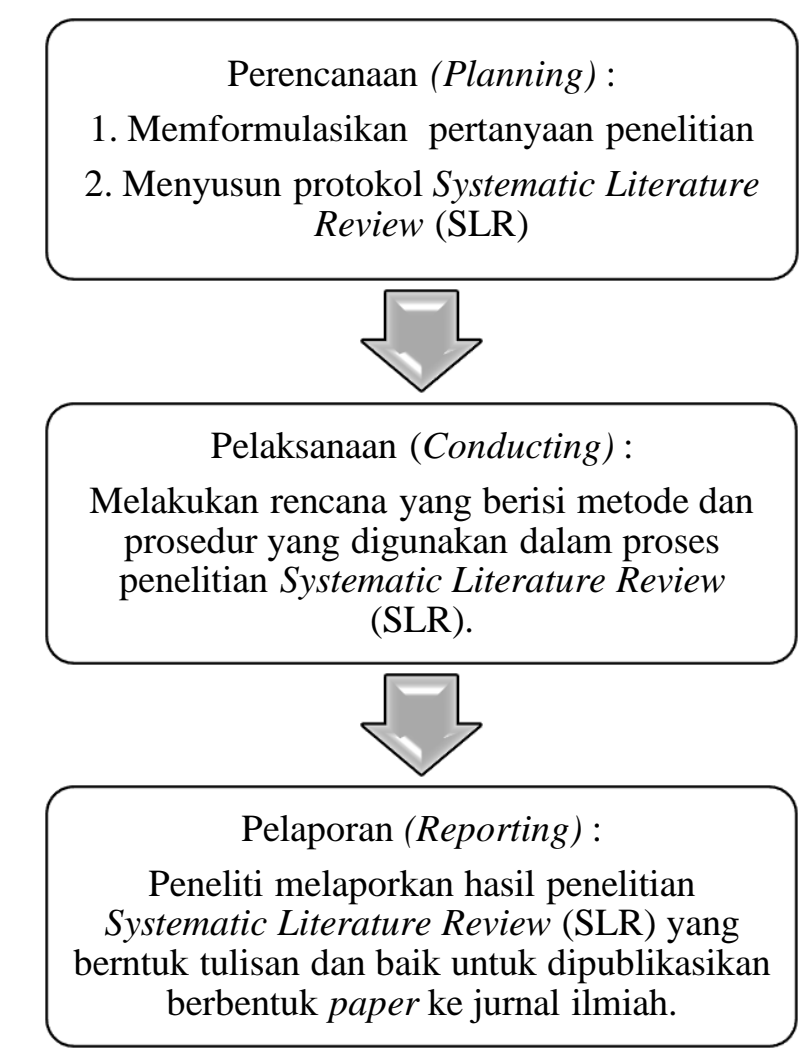

Gambar 1. Tahap penelitian metode Systematic Literature Review

Gambar.1 merupakan tahapan penelitian yang terdiri atas tahapan planning merupakan tahapan awal melakukan SLR, selanjutnya masuk ketahap conducting yaitu tahap pelaksanaan dari SLR, kemudian untuk tahap akhir masuk ke tahap Reporting yaitu merupakan tahapan penulisan SLR tersebut menjadi sebuah laporan.

\section{Research Question (Pertanyaan Penelitian)}

Pada tahap ini ditentukan pertanyaan yang sesuai dengan topik penelitian. Berikut adalah Research Question (pertanyaan penelitian) yang telah ditentukan pada penelitian ini:

RQ1 : Metode apa yang paling sering digunakan untuk melakukan penelitian terkait kualitas laporan keuangan pada koperasi?

RQ2 : Manakah jurnal yang merupakan jurnal kualitas laporan keuangan pada koperasi yang paling signifikan?

RQ3 : Apa faktor yang mempengaruhi terhadap kualitas laporan keuangan pada koperasi?

RQ4 : Apa topik dan tren penelitian yang dipilih oleh para peneliti tentang kualitas laporan keuangan pada koperasi?

RQ5 : Metode apa yang berkinerja terbaik ketika digunakan untuk kualitas laporan keuangan pada koperasi ?

\section{Research Process (Proses Pencarian)}

Research Process yang dilakukan guna mendapatkan sumber-sumber yang terkait langsung dengan persolaan yang diteliti untuk menjawab Research Question (RQ) dan referensi terkait lainnya. Proses pencarian sumber data dapat dilakukan pada alamat situs https://scholar.google.co.id/ sebagai data sekunder sebagai berikut:

(kualitas ATAU kapasitas * ATAU bobot) DAN ("laporan keuangan" *ATAU informasi keuangan

* ATAU keterangan keuangan)DAN (Koperasi) 


\section{Study Selection (Pemilihan Studi)}

Kriteria inklusi dan juga eksklusi penelitian digunakan untuk memilih studi primer maupun studi sekunder. Pada tahap ini yaitu ditentukan kriteria dari data yang ditemukan, apakah data tersebut layak digunakan sebagai sumber data untuk penelitian atau tidak. Berikut ini merupakan kriteria sebuah data dikatakan layak menjadi sumber data penelitian yaitu :

1. Data yang diperoleh memiliki rentang waktu dari 2015 sampai 2020

2. Data diperoleh dari sumber https://scholar.google.co.id/.

3. Data yang digunakan hanya paper jurnal yang berkaitan dengan kualitas laporan keuangan pada koperasi.

\section{Ekstraksi Data (Data Ekstraction)}

Pada studi utama yang sudah terpilih serta diekstraksi dan kemudian dikumpulkan berdasarkan data yang sudah berkonstribusi dalam menjawab pertanyaan pada penelitian ini yang sudah sesuai dengan topik pada permasalahan penelitian ini. Formulir ekstraksi data telah disusun untuk membantu dalam mengumpulkan data studi utama yang sesuai dengan topik permasalahn dan merupakan data yang diperlukan dalam menjawab pertanyaan penelitian. Pada proses identifikasi yang melibatkan properti data ini digunakan dalam menjawab pertanyaan penelitian yang sudah dijelaskan dan dirinci dalam penelitian ini yang kemudian akan ditunjukkan pada Tabel 1 Ekstraksi data yang akan dilakukan secara literatif.

Tabel 1. Properti Ekstraksi Data Dipetakan ke Pertanyaan Penelitian

\begin{tabular}{|l|l|}
\hline Properti & Research Question \\
\hline Identifikasi dan Publikasi & RQ1, RQ2 \\
\hline Permasalahan Penelitian & RQ4 \\
\hline Metode tingkat Kualitas Laporan Keuangan & RQ5 \\
\hline Kualitas Laporan Keuangan & RQ3 \\
\hline
\end{tabular}

\section{Kualitas Penilaian (Quality Assesment)}

Pada tahap ini data yang telah ditemukan akan dievaluasi berdasarkan pertanyaan berikut:

1. QA1 : Apakah paper jurnal diterbitkan pada rentang waktu 2015-2020?

2. QA2 : Apakah paper jurnal tersebut membahas kualitas laporan keuangan pada koperasi?

3. QA3 : Apakah paper jurnal tersebut menuliskan kualitas laporan keuangan pada koperasi?

Pada kualitas penilaian yang sudah dijelaskan diatas, nantinya akan di evaluasi kembali berdasarkan kriteria nilai yang tersedia. Sehingga setiap paper nantinya akan diberi nilai sesuai dengan pertanyaan pada kualitas penilaian. Untuk nilai yang digunakan adalah sebagai berikut:

1. Ya : untuk paper jurnal yang sesuai dengan pertanyaan pada quality assessment.

2. Tidak : untuk paper jurnal yang tidak sesuai dengan pertanyaan pada quality assessment.

\section{Pengumpulan Data (Data Collection)}

Pengumpulan data merupakan kegiatan yang dilakukan untuk mencari data di lapangan guna memperoleh suatu informasi yang dibutuhkan dalam rangka mencapai tujuan penelitian. Sumber data sekunder adalah sumber yang tidaklangsung memberikan data kepada pengumpul data, misalnya lewat orang lain atau dokumen (Sugiyono, 2014). Data sekunder dalam penelitian ini diperoleh dari beberapa tahap yaitu:

1. Studi pustaka, dilakukan dengan pengkajian data pada jurnal yang terkait metode Systematic Literature Review (SLR) yang didapatkan dari situs http://google.com dan https://scholar.google.co.id/.

2. Dokumentasi, data yang diperoleh akan disimpan ke dalam perangkat lunak Mendeley. 


\section{JURNAL AKUNTANSI, Vol. 10, No. 1, April (2021)}

\section{Jenis Data}

Jenis penelitian dalam penelitian ini menggunakan jenis penelitian kualitatif (Qualitative Research) dengan menggunakan susunan teknik interpretative dalam mengelolah sumber-sumber data yang diperoleh sehingga dapat menghasilkan jawaban atas rumusan masalah telah dijabarkan sebelumnya dengan pengertian, bukan frekuensi dari fenomena yang sering atau jarang terjadi secara alami dalam dunia social (Cooper dan Schindler, 2017)

\section{Data Analysis}

Data yang telah dikumpulkan pada tahap sebelumnya akan dianalisis pada tahap ini. Hasil yang telah dianalisis akan menjawab semua Reseacrh Question yang sebelumnya telah ditentukan.

\section{Kerangka Pikir}

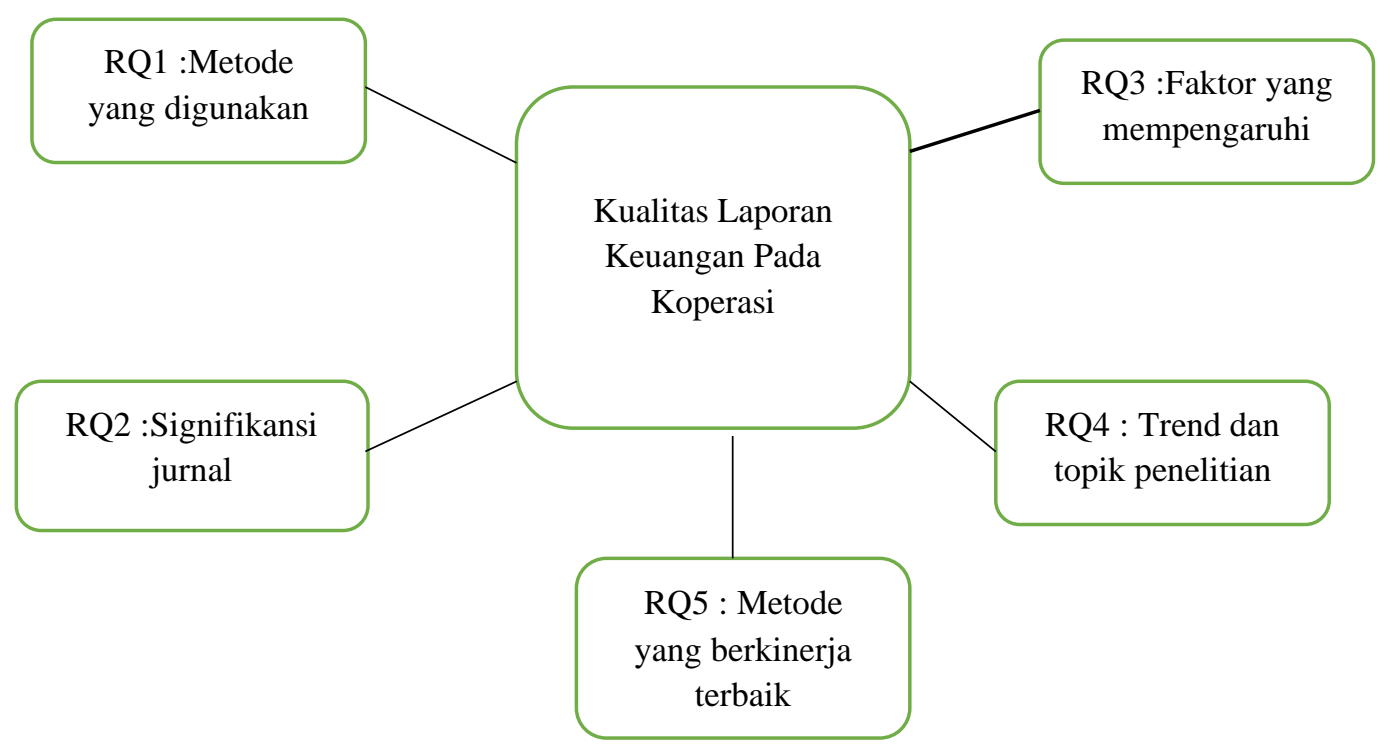

Gambar 2. Kerangka Pikir

\section{HASIL DAN PEMBAHASAN}

\section{Hasil Search Process dan Inclusion and Exclusion Criteria}

Hasil dari search process dan inclusion and exclusion criteria yaitu terdapat 561 dalam proses pencarian, tetapi hanya diambil 10 paper jurnal yang telah sesuai dengan kriteria yaitu paper jurnal diterbitkan pada rentang waktu 2015-2020 dan memiliki bahasan yang berkaitan dengan "kualitas laporan keuangan". Berikut ini merupakan tipe jurnal yang telah berhasil diperoleh:

Tabel 2. Pengelompokan Berdasarkan Jenis Jurnal

\begin{tabular}{|l|l|l|l|}
\hline No & \multicolumn{1}{|c|}{ Tipe Jurnal } & Tahun & \multicolumn{1}{c|}{ Jumlah } \\
\hline 1 & E- Jurnal Akuntansi Universitas Pendidikan Ganesha & 2015 & 2 \\
\hline 2 & E- Jurnal Akuntansi Universitas Pendidikan Ganesha & 2017 & 5 \\
\hline 3 & Jurnal Riset Akuntansi & 2019 & 1 \\
\hline 4 & Jurnal Akuntansi Keuangan dan Sistem Informasi & 2020 & 1 \\
\hline 5 & Jurnal Penelitian Teori dan Terapan Akuntansi & 2020 & 1 \\
\hline
\end{tabular}

\section{Hasil Dari RQ1 : Metode yang Digunakan}

Berdasarkan Research Question 1 atau RQ1 tentang metode yang sering digunakan untuk melakukan penelitian terkait kualitas laporan keuangan pada koperasi, didapatkan hasil yaitu kategori paper berdasarkan teknik pengumpulan datanya. Dari hasil yang terlihat dari tabel 3 menunjukkan 


\section{JURNAL AKUNTANSI, Vol. 10, No. 1, April (2021)}

bahwa semua penelitian tersebut menggunakan teknik pengumpulan data kuesioner. Jumlah responden yang paling banyak digunakan oleh para peneliti sebanyak 38 responden.

Tabel 3. Kategori Teknik Pengumpulan Data

\begin{tabular}{|l|l|l|l|l|}
\hline No & $\begin{array}{c}\text { Teknik } \\
\text { Pengumpulan Data }\end{array}$ & $\begin{array}{c}\text { Jumalah } \\
\text { Responden }\end{array}$ & \multicolumn{1}{|c|}{ Penelitian } & Jumlah \\
\hline 1 & Kuesioner & 38 & $\begin{array}{l}\text { (Sapitri et al., 2016), (Dewi et } \\
\text { al., 2017), (Oktaviyanti, 2017) }\end{array}$ & 3 \\
\hline & & 39 & (Sutawan et al., 2015) & 1 \\
\hline & & 40 & (Arismawati et al., 2017) & 1 \\
\hline & & 54 & (Septyani, 2020) & 1 \\
\hline & & 58 & (Indrawan et al., 2017) & 1 \\
\hline & & 64 & (Mahayani et al., 2017) & 1 \\
\hline & & 84 & (Dewi, 2019) & 1 \\
\hline & & 120 & (Riyadi, 2020) & 1 \\
\hline
\end{tabular}

\section{Hasil Dari RQ2 : Signifikansi Jurnal}

Berdasarkan Research Question 2 atau RQ2 tentang jurnal yang paling signifikan dibidang kualiatas laporan keuangan pada koperasi, ada 10 jurnal yang menganilisis kualitas laporan keuangan pada koperasi. Dari hasil yang terlihat pada tabel 4 menunjukkan bahwa setiap tahun terdapat jurnal yang membahas mengenai kualitas laporan keuangan pada koperasi, bahkan terbanyak pada tahun 2017 beberapa jurnal dengan pendekatan kuantitatif . Tahun 2016 tidak ada yang meneliti mengenai kualitas laporan keuangan pada koperasi, melainkan pada perusahaan lain. Pada tahun 2015 dan 2019 masingmasing tahun hanya terdapat satu jurnal yang membahas tentang kualitas laporan keuangan pada koperasi, sedangkan pada tahun 2020 terdapat 2 jurnal yang membahas mengenai kualitas laporan keuangan pada koperasi.

Tabel 4. Kategori Signifikan Jurnal

\begin{tabular}{|l|l|l|}
\hline No & \multicolumn{1}{|c|}{ Nama Penerbit } & \multicolumn{1}{|c|}{ Kategori Dan Tahun } \\
\hline 1 & E- Jurnal Akuntansi Universitas Pendidikan Ganesha & 2015 \\
\hline 2 & E- Jurnal Akuntansi Universitas Pendidikan Ganesha & 2015 \\
\hline 3 & E- Jurnal Akuntansi Universitas Pendidikan Ganesha & 2017 \\
\hline 4 & E- Jurnal Akuntansi Universitas Pendidikan Ganesha & 2017 \\
\hline 5 & E- Jurnal Akuntansi Universitas Pendidikan Ganesha & 2017 \\
\hline 6 & E- Jurnal Akuntansi Universitas Pendidikan Ganesha & 2017 \\
\hline 7 & E- Jurnal Akuntansi Universitas Pendidikan Ganesha & 2017 \\
\hline 8 & Jurnal Riset Akuntansi & 2019 \\
\hline 9 & Jurnal Akuntansi Keuangan dan Sistem Informasi & ISSN: 2721- 060X (2020) \\
\hline 10 & Jurnal Penelitian Teori dan Terapan Akuntansi & e-ISSN 2528- 2581 (2020) \\
\hline
\end{tabular}

\section{Hasil Dari RQ3: Faktor yang Mempengaruhi Kualitas Laporan Keuangan Koperasi}

Berdasarkan Research Question 3 atau RQ3 tentang faktor yang mempengaruhi kualitas laporan keuangan, didapatkan hasil yaitu kategori paper berdasarkan faktor yang mempengaruhi kualitas laporan keuangan. Dari hasil yang terlihat pada tabel 5 menunjukkan bahwa pengendalian internal akuntansi menjadi faktor yang paling mempengaruhi kualitas laporan keuangan berdasarkan penelitian yang terdapat paper-paper tersebut. Selanjutnya faktor sumber daya manusia dan pemanfaatan teknologi informasi menjadi faktor tertinggi kedua. Faktor tertinggi ketiga pemahaman akuntansi. 
Tabel 5. Kategori Faktor Kualitas Laporan Keuangan

\begin{tabular}{|l|l|l|c|}
\hline No & \multicolumn{1}{|c|}{ Faktor } & \multicolumn{1}{|c|}{ Peneliti } & Jumlah \\
\hline 1 & Sumber Daya Manusia & $\begin{array}{l}\text { (Sapitri et al., 2016), (Mahayani et al., } \\
\text { 2017), (Indrawan et al., 2017), (Oktaviyanti, } \\
\text { 2017), (Dewi, 2019), (Ismunawan, 2020) }\end{array}$ & 6 \\
\hline 2 & $\begin{array}{l}\text { Pengendalian Internal } \\
\text { Akuntansi }\end{array}$ & $\begin{array}{l}\text { (Sapitri et al., 2016), (Sutawan et al., 2015), } \\
\text { (Mahayani et al., 2017), (Dewi et al., 2017), } \\
\text { (Oktaviyanti, 2017), (Dewi, 2019), } \\
\text { (Ismunawan, 2020) }\end{array}$ & 7 \\
\hline 3 & $\begin{array}{l}\text { Pemanfaatan } \\
\text { Teknologi Informasi }\end{array}$ & $\begin{array}{l}\text { (Sapitri et al., 2016), (Mahayani et al., } \\
\text { 2017), (Dewi et al., 2017), (Indrawan et al., } \\
\text { 2017), (Riyadi, 2020), (Ismunawan, 2020) }\end{array}$ & 6 \\
\hline 4 & Pengalaman kerja & (Indrawan et al., 2017), (Dewi, 2019) & 2 \\
\hline 5 & Pemahaman akuntansi & $\begin{array}{l}\text { (Dewi et al., 2017), (Indrawan et al., 2017), } \\
\text { (Arismawati et al., 2017), (Riyadi, 2020), }\end{array}$ & 5 \\
\hline 6 & Pengaruh stres kerja & (Ismunawan, 2020) & 1 \\
\hline 7 & Tingkat Pendidikan & (Arismawan et al., 2015) & 1 \\
\hline 8 & Budaya Etis Organisasi & (Oktaviyanti, 2017) & 1 \\
\hline
\end{tabular}

\section{Hasil Dari RQ4: Trend dan Topik Penelitian}

Berdasarkan Research Question 4 atau RQ4 tentang topik dan trend penelitian yang signifikan di bidang kualitas laporan keuangan. Analisis studi primer yang akan dipilih mengungkapkan bahwa penelitian kualitas laporan keuangan pada koperasi berfokus pada 5 topik yaitu:

1. Mengidentifikasi permasalahan kualitas laporan keuangan pada koperasi.

2. Mencari permasalahan terbanyak yang dihadapi oleh kualitas laporan keuangan pada koperasi.

3. Menemukan penyebab terjadinya permasalahan kualitas laporan keuangan pada koperasi .

4. Memilih solusi jawaban dari permasalahan kualitas laporan keuangan pada koperasi.

5. Membuat kesimpulan solusi jawaban terlengkap dan terbaik dari semua penelitian tentang kualitas laporan keuangan pada koperasi.

Pada topik pertama yaitu mengidentifikasi permasalahan kualitas laporan keuangan pada koperasi. Sapitri et al. (2016) dan Kadek et al. (2017) membahas tentang sumber daya manusia dan pengendalian internal. Riyadi (2020) membahas tentang optimalisasi. Pada penelitian Arismawati et al. (2017) membahas pentingnya tingkat pendidikan bagi Sumber Daya Manusia yang berkualitas dan fasilitas pada sumber daya oleh manusia dan pengaruh pemahaman akuntansi, teknologi informasi terhadap kualitas laporan keuangan pada koperasi oleh Ismunawan (2020)

Pembahasan topik kedua tentang permasalahan terbanyak yang dihadapi oleh kualitas sumber daya manusia pada koperasi adalah tentang sumber daya manusia, pengendalian internal dan teknologi informasi yang dibahas oleh Sapitri et al. (2016), Putu \& Luh (2017), dan Oktaviyanti, et al. (2017). Kualitas sumber daya manusia merupakan salah satu faktor penting terkait pengendalian internal yang dihadapi, pengendalian internal membantu dalam mengelola sumber daya manusia dalam menjalankan tugas dan tanggungjawabnya, kualitas sumber daya manusia juga dapat berupa pemahaman teknologi informasi yang dikuasai oleh sumber daya manusia dalam menjalankan tugasnya maupun tanggungjawabnya.

Topik ketiga menekan penyebab terjadinya permasalahan kualitas sumber daya manusia pada koperasi adalah tentang stress kerja dan motivasi sangat penting untuk koperasi, karena itu untuk mengelola stress dan mampu memberikan motivasi-motivasi positif terhadap anggota koperasi Sutawan et al. (2015) dan Ayu \& Putu (2017) mengatakan dalam peningkatan kualitas karyawan dengan mengadakan pelatihan pada pengurus koperasi tentang sistem informasi akuntansi sebagai upaya meningkatkan kualitas laporan keuangan. Untuk penelitian Putu \& Luh (2017) juga mengatakan 


\section{JURNAL AKUNTANSI, Vol. 10, No. 1, April (2021)}

peningkatan sumber daya manusia melalui pelatihan yang kompeten dalam bidang akuntansi dan dengan adanya pengendalian internal ditingkatkan guna menghindari kecurangan yang akan berdampak pada kualitas laporan keuangan pada koperasi dan pentingnya sistem pengendalian internal, komitmen organisasi dalam pengelolaannya (Kadek et al., 2017). Peningkatan kualitas karyawan dengan mengadakan pelatihan pada pengurus koperasi tentang sistem informasi akuntansi sebagai upaya meningkatkan kualitas laporan keuangan.

Topik keempat memilih solusi jawaban dari permasalahan kualitas laporan keuangan pada koperasi, Riyadi (2020) mengatakan perlunya manajemen koperasi lebih memperhatikan sistem yang ada untuk meningkatkan pelatihan akuntansi koperasi berbasis komputer, sama dengan pendapat Putu $\&$ Luh (2017). Selain itu peningkatan sumber daya manusia melalui pelatihan yang kompeten dalam bidang akuntansi untuk menghasilkan laporan keuangan yang baik dan pengendalian internal guna menghindari kecurangan yang akan berdampak pada kualitas laporan keuangan guna meningkatkan kualitas laporan keuangan. Dewi (2019) dengan jurnal yang berbeda namun topiknya masih sama tentang kualitas laporan keuangan juga menjawab permasalahan sumber daya manusia dan pengendalian internal dengan melakukan proses seleksi yang harus lebih di perketat guna mendapatkan sumber daya yang berkualitas dan akan mengahasilkan calon-calon anggota atau karyawan yang lebih berkualitas dan kompetitif. Untuk menjawab sumber daya manusia, pemahaman akuntansi dan pengendalian internal maka perlu adanya manajemen meningkatkan pengendalian internal dan sumber daya manusia yang dapat mempengaruhi kualitas laporan keuangan koperasi dengan cara komitmen organisasi, tingkat pendidikan, pengalaman kerja dan pemanfaatan teknologi informasi dengan baik (Oktaviyanti, et al., 2017).

Topik kelima yaitu solusi jawaban terlengkap dan terbaik dari semua penelitian tentang kualitas laporan keuangan pada koperasi adalah dengan proses seleksi yang diperketat demi mendapatkan sumber daya manusia berkuliatas (Dewi, 2019), digabungkan dengan motivasi positif untuk mengurangi stress kerjadapat meningkatkan kualitas laporan keuangan pada koperasi terhadap (Sutawan et al., 2015) dan tingkat pendidikan yang semakin tinggi akan semakin meningkatkan kualitas laporan keuangan, karena kemampuan untuk mengelola dan memahami akuntansi koperasi lebih mudah (Kadek et al., 2017). Untuk mencapai tujuan terbeut maka perlu adanya pelatihan yang kompeten dalam bidang akuntansi dan peengendalian internal ditingkatkan guna menghindari terjadinya kecurangan yang akan berdampak pada koperasi Mahayani et al. (2017).

\section{Hasil dari RQ5: Metode yang Berkinerja Terbaik}

Berdasarkan Research Question 5 atau RQ5 tentang metode yang berkinerja terbaik ketika digunakan untuk kualitas laporan keuangan pada koperasi , didapatkan hasil yaitu kategori paper. Hampir semua penelitian menggunakan metode kuantitatif, baik dengan studi pustaka (library research), observasi, wawancara mendalam. Metode yang berkinerja terbaik digunakan meneliti tentang kualitas laporan keuangan pada koperasi adalah metode kuantitatif mengapa demikian? Karena dengan metode tersebut permasalahan yang ada akan dijawab dalam suatu penelitian untuk memperoleh hasil analisis yang terukur mengenai gambaran atau konsep kualitas laporan keuangan pada koperasi.

Beberapa jurnal tentang kualitas laporan keuangan pada koperasi yang direview ada beberapa yang hasilnya tidak signifikan setelah dilakukan uji pengaruh antara variabel sumber daya manusia, pengendalian internal, pengendalian internal dan teknologi informasi seperti yang diteliti oleh (Ismunawan, 2020). Pada sebuah koperasi, pemahaman akuntansi tidak berpengaruh signifikan dan positif dan teknologi informasi tidak berpengaruh postif terhadap kualitas laporan keuangan pada koperasi tersebut karena pemahaman akuntansi kurang dalam pembuatan laporan keuangan dan dalam penggunaan teknologi ninformasi yang masih jarang dimanfaatkan secara efektif dan maksimal, sementara koperasi tersebut dalam sumber daya manusia dan sistem pengendaliannya sudah baik. 


\section{JURNAL AKUNTANSI, Vol. 10, No. 1, April (2021)}

\section{PENUTUP \\ Simpulan}

Berdasarkan hasil penelitian yang sudah dilakukan, maka dapat diambil keseimpulan bahwa hasil Systematic Literature Review dari semua penelitian yang terdapat pada jurnal sudah dipubikasikan sejak tahun 2015 sampai tahun 2020 dan bertujuan untuk mengetahui faktor apa saja yang mempengaruhi kualitas laporan keuangan, mengidentifikasi dan menganalisis metode yang sering digunakan, signifikan jurnal, topik dan trend serta metode yang berkinerja terbaik dalam pengambilan data. Terdapat 10 jurnal yang diperoleh berdasarkan hasil seleksi pencarian studi. Faktor yang mempengaruhi kualitas laporan keuangan pada koperasi adalah sumber daya manusia, pengendalian internal akuntansi, pemanfaatan teknologi informasi, pengalaman kerja, pemahaman akuntansi, pengaruh stres kerja, tingkat pendidikan dan budaya etis organisasi. Dari beberapa faktor kualitas laporan keuangan terdapat faktor yang mempengaruhi bagi kualitas laporan keuangan pada koperasi yaitu sumber daya manusia, pengendalian internal akuntansi dan pemanfaatan teknologi informasi.

Hasil dari research question (RQ:1) pada metode yang sering digunakan untuk melakukan penelitian terkait kualitas laporan keuangan pada koperasi, didapatkan hasil yaitu kategori paper berdasarkan teknik pengumpulan datanya menggunakan teknik pengumpulan data kuesioner. Jumlah responden yang paling banyak digunakan oleh para peneliti sebanyak 38 responden. Selanjutnya hasil dari research question (RQ:2) yaitu jurnal yang paling signifikan dibidang kualiatas laporan keuangan pada koperasi, ada 10 jurnal yang menganilisis kualitas laporan keuangan pada koperasi. Bahwa setiap tahun terdapat jurnal yang membahas mengenai kualitas laporan keuangan pada koperasi, bahkan terbanyak pada tahun 2017 beberapa jurnal dengan pendekatan kuantitatif. Tahun 2016 tidak ada yang meneliti mengenai kualitas laporan keuangan pada koperasi, melainkan pada perusahaan lain. Pada tahun 2015 dan 2019 masing-masing tahun hanya terdapat satu jurnal yang membahas tentang kualitas laporan keuangan pada koperasi, sedangkan pada tahun 2020 terdapat 2 jurnal yang membahas mengenai kualitas laporan keuangan pada koperasi.

Hasil untuk research question (RQ:3) yaitu tentang faktor yang mempengaruhi kualitas laporan keuangan, didapatkan hasil yaitu kategori paper berdasarkan faktor yang mempengaruhi kualitas laporan keuangan pada koperasi. Bahwa pengendalian internal akuntansi menjadi faktor yang paling mempengaruhi kualitas laporan keuangan berdasarkan penelitian yang terdapat paper-paper tersebut. Selanjutnya faktor sumber daya manusia dan pemanfaatan teknologi informasi menjadi faktor tertinggi kedua. Faktor tertinggi ketiga pemahaman akuntansi.

Selanjutnya untuk research question (RQ:4) untuk topik dan trend penelitian yang signifikan di bidang kualitas laporan keuangan pada koperasi sebagai berikut : 1) Dalam peningkatan kualitas karyawan dengan cara mengadakan pelatihan tentang pemahaman akuntansi upaya meningkatkan pemahaman yang baik dan berkualitas. 2) Melakukan pelatihan yang kompeten dalam bidang akuntansi dan pengendalian internal untuk menghindari kecurangan yang akan berdampak buruk bagi koperasi. 3) Proses seleksi pada sumber daya manusi harus lebih di perketat untuk mendapatkan sumber daya manusia yang berkualitas, karena dengan adanya persaingan yang lebih ketat akan menghasilkan caloncalon karyawan berkualitas yang dan kompetitif. 4) Manajemen koperasi lebih memperhatikan sistem pengendalian internal yang ada dengan lebih meningkatkan pelatihan akuntansi koperasi yang berbasis komputer guna meningkatkan pemahaman akuntansi kepada sumber daya manusia bahwa pentingnya sistem pengendalian internal. 5) Memberikan motivasi kepada sumber daya manusia agar tidak terjadi stress kerja dan membuka wawasan yang lebih akan pentingnya kualitas laporan keuangan bagi koperasi.

Hasil dari research question (RQ:5) tentang metode yang berkinerja terbaik ketika digunakan untuk kualitas laporan keuangan pada koperasi, didapatkan hasil yaitu kategori paper. Sebagian keseluruhan penelitian menggunakan metode kuantitatif, baik dengan studi pustaka (library research), observasi, wawancara mendalam. Metode yang berkinerja terbaik digunakan meneliti tentang kualitas laporan keuangan pada koperasi adalah metode kuantitatif. 


\section{Saran}

Saran untuk peneliti Systematic Literature Review selajutnya diharapkan bisa dijadikan perbandingan hasil analisis yang berbeda mengenai Systematic Literature Review faktor yang mempengaruhi kualitas laporan keuangan pada koperasi dan mampu untuk memberikan penjelasan lebih rinci. Berdasarkan hasil pembahasan dan kesimpulan diatas, maka saran yang dapat diberikan adalah pada literature review dinyatakan bahwa belum adanya penelitian mengenai kualitas laporan keuangan pada koperasi, maka disarankan untuk peneliti selanjutnya melakukan penelitian mengenai kualitas laporan keuangan sehingga nantinya dapat memberikan sumber informasi yang valid untuk pengembangan dalam penelitian mengenai faktor yang mempengaruhi kualitas laporan keuangan pada koperasi. Pada penelitian ini diharapkan nantinya dapat menjadi dasar pengembangan pada kualitas laporan keuangan bagi pihak koperasi. Hasil penelitian yang dihasilkan dari penelitian ini diharapkan dapat membantu dan menjadi salah satu tolak ukur kualitas laporan keuangan yang dapat digunakan oleh koperasi untuk melakukan pengembangan dan kinerja koperasi. Hasil dari penelitian ini diharapkan nantinya dijadikan pengembangan pengetahuan bagi peneliti selanjutnya.

\section{REFERENSI}

Arismawati, K. N., Sulindawati, N. L. G. E., \& Atmadja, A. T. (2017). Pengaruh Tingkat Pendidikan, Pemahaman, Akuntansi Koperasi Berbasis SAK-ETAP, Kematangan Usia, Perilaku, dan Efektivitas Kinerja Terhadap Kualitas Laporan Keuangan Koperasi Simpan Pinjam di Kabupaten Buleleng (Studi Kasus pada Koperasi Simpan Pinjam di Ke. E-Journal S1 Ak Universitas Pendidikan Ganesha, $8(2), \quad 1-10$. https://ejournal.undiksha.ac.id/index.php/S1ak/article/view/10426

Baridwan, Z. (2004). Intermediate Accounting. Yogyakarta: BPFE.

Cooper, E \& Schindler, S. (2017). Metode Penelitian Bisnis. Jakarta: Salemba Empat.

Dewi, P. (2019). ... Experience, and Internal Control Systems on the Quality of Financial Statements (Case Study of Cooperatives in Gianyar Regency .... Jurnal Riset Akuntansi (JUARA), 1-10. http://e-journal.unmas.ac.id/index.php/juara/article/view/598

Dewi, P. E. D. M. (2019). Analysis of human resources, training quality, work experience, and internal control systems on the quality of financial statements (case study of cooperatives in gianyar regency). $1-10$.

Dewi Puspa Ayu, L., Kurniawan Sukma, P., \& Sulindawati Erni, N. L. G. (2017). Pengaruh Pemahaman Akuntansi Koperasi Berbasis SAK-ETAP, Pemanfaatan Sistem Informasi Akuntansi dan Pengendalian Intern Akuntansi terhadap Kualitas Laporan Keuangan. Jurnal Ilmiah Mahasiswa Akuntansi UNDIKSHA, 1 .

Hendrojogi. (1997). Koperasi: Azas - azas Teori dan Praktek. Jakarta : Raja Grafindo Persada.

Indrawan, K O, Wahyuni, M. A., \& Yuniarta, G. A. (2017). Pengaruh Kualitas Sumber Daya Manusia di Bidang Akuntansi, Teknologi Informasi dan Penerapan Standar Akuntansi terhadap Kualitas Laporan Keuangan pada Koperasi di Kabupaten Buleleng. JIMAT (Jurnal Ilmiah Mahasiswa Akutansi) Undiksha, 7(1). https://ejournal.undiksha.ac.id/index.php/S1ak/article/view/9677

Indrawan, Kadek Okik, Wahyuni, M. A., \& Yuniarta, G. A. (2017). Pengaruh Kualitas Sumber Daya Manusia di Bidang Akuntansi, Teknologi Informasi dan Penerapan Standar Akuntansi terhadap Kualitas Laporan Keuangan pada Koperasi di Kabupaten Buleleng. 1(1).

Ismunawan, Septyani, N. (2020). Analisis Faktor-Faktor Yang Mempengaruhi Kualitas Laporan Keuangan. Warta LPM, 23(1). https://doi.org/10.23917/warta.v23i1.10202

Kitchenham, B. and Charters, S. (2007). Guidelines for Performing Systematic Literature Reviews in Software Engineering, Technical Report EBSE 2007-001. Keele University and Durham University Joint Report, 2.

Luh Ayu Puspa Dewi, Putu Sukma Kurniawan, N. L. G. E. S. (2017). Pengaruh Pemahaman Akuntansi Koperasi Berbasis SAK-ETAP Pengendalian Intern Akuntansi Terhadap Kualitas Laporan Keuangan (Studi Kasus Pada Koperasi Simpan Pinjam Di Kecamatan Buleleng). 1.

Mahayani, N. P. L., Sulindawati, N. L. G. E., \& Dewi, P. E. D. Ma. (2017). Pengaruh Kualitas Sumber Daya Manusia Bidang Akuntansi, Sistem Pengendalian Internal Dan Pemanfaatan Teknologi 
Informasi Terhadap Kualitas Laporan Keuangan (Studi Pada Koperasi Simpan Pinjam Di Kabupaten Jembrana). E-Journal S1 Ak Universitas Pendidikan Ganesha Jurusan Akuntansi Program S1, 8(2).

Munawir, S. (2000). Analisa Laporan Keuangan. Yogyakarta: Liberty.

Ni Putu Lia Mahayani, Ni Luh Gede Erni Sulindawati, P. E. D. M. D. (2017). Pengaruh Kualitas Sumber Daya Manusia Bidang Akuntansi, Sistem Pengendalian Internal Dan Pemanfaatan Teknologi Informasi Terhadap Kualitas Laporan Keuangan (Studi Pada Koperasi Simpan Pinjam Di Kabupaten Jembrana). 1.

ojk.go.id. (1992). Undang-Undang Nomor 25 Tahun 1992. 21 Oktober.

Oktaviyanti, Herawati, \& Atmadja. (2017). Pengaruh Pengendalian Internal, Kompetensi Sumber Daya

Manusia, Dan Budaya Etis Organisasi Terhadap Kualitas Laporan Keuangan (Studi Kasus

Koperasi Simpan Pinjam Di Kecamatan Buleleng). JIMAT (Jurnal Ilmiah Mahasiswa Akuntansi S1), 8(2).

Oktaviyanti, M., Herawati, N. T., Wikrama, A., \& Atmadja, T. (2017). Pengaruh Pengendalian Internal, Kompetensi Sumber Daya Manusia, Dan Budaya Etis Organisasi Terhadap Kualitas Laporan Keuangan (Studi Kasus Koperasi Simpan Pinjam Di Kecamatan Buleleng). 1.

Peraturan.bpk. (1967). Undang-undang (UU) tentang Pokok-Pokok Perkoperasian. 18 Desember.

Roviyantie, D. (2011). Pengaruh Kompetensi Sumber Daya Manusia dan Penerapan Sistem Akuntansi Keuangan Daerah Terhadap Kualitas Laporan Keuangan Daerah. Jurnal Akuntansi Universitas Siliwangi.

Sapitri, N. M. T., Purnamawati, i G. A., \& Sujana, E. (2016). Pengaruh Kapasitas Sumber Daya Manusia, Pengendalian Internal Akuntansi, dan Pemanfaatan Teknologi Informasi Terhadap Kualitas Laporan Keuangan (Studi Kasus Koperasi Simpan Pinjam Di Kecamatan Buleleng). EJournal S1 Ak Universitas Pendidikan Ganesha, 3(1), 1.

Sugiyono, P. (2014). Metode Kuantitatif Kualitatif dan R \& D. In Jakarta: Alfabeta.

Suryani, L. \& M. (2014). Metode SLR untuk Mengidentifikasi Isu-Isu dalam Software Engineering. SATIN (Sains Dan Teknol. Informasi), Vol 3, No.

Sutawan, I. M. E., Darmawan, N. A. S., \& Yuniarta, G. A. (2015). Pengaruh Stres Kerja, Motivasi Dan Sistem Pengendalian Intern Terhadap Kualitas Laporan Keuangan Koperasi (Studi Kasus pada Koperasi di Kabupaten Buleleng). E-Journal S1 Ak Universitas Pendidikan Ganesha, 3(1).

Wulan Riyadi. (2020). Pemanfaatan Sistem Informasi Dan Pemahaman Akuntansi Pengaruh Terhadap Kualitas Laporan Keuangan Pada Koperasi Di Kabupaten Majalengka. 1(1), 97-109. 